\title{
Questioning the implementation of habitat corridors: a case study in interior São Paulo using ants as bioindicators
}

\author{
Lapola, DM. ${ }^{\mathrm{a}, \mathrm{b} *}$ and Fowler, $H \mathrm{G}^{\mathrm{a}}$ \\ aDepartamento de Ecologia, Universidade Estadual Paulista - UNESP, CP 199, Rio Claro, SP, Brazil \\ ${ }^{\mathrm{b}}$ Center for Environmental Systems Research, University of Kassel, 34125 Kassel, Germany \\ *e-mail: lapola@usf.uni-kassel.de \\ Received January 27, 2006 - Accepted August 10, 2006 - Distributed February 29, 2008
}

(With 2 figures)

\begin{abstract}
In this paper we operated ant collections in three inland Atlantic forest fragments and in the neighboring Edmundo Navarro de Andrade State Forest (FEENA), an Eucalyptus plantation located in Rio Claro, interior of São Paulo State. We show that the ant communities of the native forest fragments are more similar among themselves than to the ant community of FEENA. Thus we evidence that, in addition to the clear difference in vegetation segment, other components of the biota (like ants) can be different between FEENA and the native forest fragments. Our results conveniently served as a basis to discuss the proposal of connecting FEENA to the three native forest fragments by a habitat corridor. These fragments are important to conservation purposes since they represent the biggest areas of native vegetation in the region.
\end{abstract}

Keywords: ants, habitat corridors, forest fragmentation, reforestation, Atlantic Forest.

\section{Questionando a implementação de corredores de habitat: um estudo de caso no interior de São Paulo usando formigas como bioindicadores}

\begin{abstract}
Resumo
Neste trabalho operamos coletas de formigas em três fragmentos de Mata Atlântica e na vizinha Floresta Estadual Edmundo Navarro de Andrade (FEENA), um reflorestamento de eucaliptos em Rio Claro, interior de São Paulo. Demonstramos que as comunidades de formigas dos fragmentos de floresta nativa são mais parecidas entre si do que com a da FEENA. Desse modo evidenciamos que além da clara diferença no segmento vegetacional, outros componentes da biota (como as formigas) podem ser diferentes entre a FEENA e os fragmentos de floresta nativa. Nossos resultados oportunamente serviram como base para discussão sobre a proposta de se unir através de um corredor ecológico a FEENA a esses fragmentos de floresta nativa. Tais fragmentos são importantes para fins de conservação uma vez que representam as maiores áreas de vegetação nativa da região.
\end{abstract}

Palavras-chave: formigas, corredores ecológicos, fragmentação florestal, reflorestamento, Mata Atlântica.

\section{Introduction}

The last few centuries are marked by a large conversion of tropical forests into a mosaic of habitats altered by human action, impelled mainly by world population growth and socioeconomic pressures (Gascon et al., 2002). These pressures acted in such manner in São Paulo State that, nowadays, only about $13.94 \%$ of the native vegetation cover still remains. Moreover, only half of this value (about 7\%) represents primary forests, in a State that once had $82 \%$ of its area occupied by forests (Kronka et al., 2005; Zorzetto et al., 2003). Particularly the forests located in the interior of the state suffered the major deforestation rates, due to the region's smooth topography and fertile soils that stimulated human occupation and agricultural development. These interior woods, formally named seasonal semi-deciduous forests, collapsed mainly in the late $19^{\text {th }}$ century giving place to the expansion of coffee plantation and, more recently, to other commercial cultures (sugar cane, orange and pastures) and non-native reforestations (Dean, 1995). As a consequence of this destruction, biodiversity has been reduced and the dynamics of many populations and communities were interrupted (Brown and Brown, 1992).

In this context, one of the practices that have been proposed for biodiversity maintenance and increase of forested areas in the region is the implementation of habitat corridors (or ecological corridors or even vegetation corridors) connecting the remaining forest fragments. Theoretically, these habitat corridors would significantly 
accentuate the movement of organisms between spots in a landscape, thus reducing the extinction probability of populations in fragments (Wilson and Willis, 1975). Despite of the uncertainty about the efficiency of these corridors (Noss, 1987; Simberloff et al., 1992; Beier and Noss, 1998; Levey et al., 2005) their implementation to enlarge habitats connectivity has been widely employed in conservation efforts in Brazil (e.g. Conservation International Brasil, 2006; IPÊ, 2006; Furtado, 2005). Therefore, it is argued that the concept of habitat corridors was inserted prematurely in the public policies domain, without previous research showing its efficiency (Noss, 1987; but see Levey et al., 2005).

In São Paulo, a State that has more than 3\% (770.000 ha) of its area occupied by Eucalyptus and Pinus reforestations, the occurrence of remaining fragments of native forest nearby these non-native forests is common (Kronka et al., 2005). But, until present, the dynamic of movement of the biota between native Atlantic Forest remnants and non-native reforestations that occur in such close proximity has been poorly studied (but see Willis and Oniki, 2002; Willis, 2003). The older reforestations generally possess a considerable number of native species, in view of the time that they have been in process of ecological succession (Moura, 1998). In some cases it makes them seem like a native forest, what can lead a non-experienced observer to judge being equal these two different kinds of vegetation (an old reforestation and a native forest remnant).

In the case here studied, there exists a proposal of connecting, through habitat corridors, an Eucalyptus state forest to three remaining fragments of Atlantic Forest located inside a private property. This proposal rose from concise suggestions in scientific articles (e.g. Willis, 2003) and from a lot of informal communications between researchers and decision-makers. The incipient debate culminated in a concern of the state forest administration, due to the lack of technical-scientific information showing the viability, efficiency and real importance of those corridors (FEENA administration, pers. com.). In spite of having not been implemented yet, the debate over this proposal is based on the argument that the vegetation of the reforestation is advanced in age and displays characteristics of a native forest. It is also suggested that an exchange of individuals between the areas would enrich the community of this non-native forest, thus quickening the process of succession and making the reforestation become similar to the neighboring native forest more rapidly.

One prudent mind would think that previous studies on the biota, or at least on the principal groups of organisms in the areas to be united by the corridors are of extreme importance. That is because one of the areas (or fragments) may hold exotic or tramp species that could threaten the communities of the other area, outcompeting native species (Williamson and Fitter, 1996; McGlynn, 1999; Schultz and McGlynn, 2000). Since the cited reforestation possesses non-native elements in its vegetation segment (Eucalyptus and Pinus), probably, in additional segments of the biota, it may also hold other species that are not present in the native forest fragments (Bierregaard et al., 1992; Willis, 2003). On the contrary, if the vegetation of the areas in the referred proposal is indeed similar, other segments of the biota are also expected to be similar, like birds, mammals or insects communities.

Therefore, in order to access the resemblance of one component of the biota of these two areas, we operated ant (Hymenoptera: Formicidae) collections, since they make up an extremely diverse group, with many attributes that make them ideal organisms for studies dealing with comparative biodiversity. To cite some: numerical and biomass dominance in almost every terrestrial habitat; they have a relatively simple taxonomy; they are easy-tocollect organisms; they have stationary habits (nests), allowing them to be easily resampled; they play important roles in ecosystems, including interactions with other organisms in any trophic level; they are sensible to environmental changes, indicating the state in which the ecosystem is found (Alonso and Agosti, 2000).

In this paper we determine the level of similarity of the ant communities in the four isolated forest areas mentioned above (three native forest fragments and a non-native Eucalyptus reforestation). We evidence that, as in the vegetation segment, we can also find differences in other components of the biota (like ants) of the reforestation and of the native forest fragments. With our results, the validity of connecting such areas through habitat corridors is discussed, keeping in mind that the practice of implementing corridors could become common in Southeastern Brazil.

\section{Materials and Methods}

\subsection{Study area}

Fieldwork was conducted during 2003-2004, in a site located in the limit between the municipalities of Rio Claro and Araras, São Paulo State, Brazil (Figure 1). We collected ants in three inland Atlantic Forest fragments and in a neighboring reforestation (Floresta Estadual Edmundo Navarro de Andrade - FEENA). The latter is compounded almost entirely by Eucalyptus cultivation, and is currently administrated by the Instituto Florestal, a governmental agency that administrates all conservation units in the State. Mean annual precipitation in the region is of $1600 \mathrm{~mm}$, while the mean elevation is about $630 \mathrm{~m}$ and the predominant soils are red ferralsols (latosols in the Brazilian classification) (Pagano et al., 1995).

The three forest fragments $\left(22^{\circ} 20^{\prime} \mathrm{S}\right.$ and $\left.47^{\circ} 29^{\prime} \mathrm{W}\right)$, usually called "Mata São José", will be referred here as MSJ1 (the southern fragment), MSJ2 (the central fragment), MSJ3 (the northern fragment), and only MSJ when concerning all the three fragments. Each one has respectively 230, 185 and 165 ha and the mean distance among them is approximately $500 \mathrm{~m}$. They are located inside a private property named Fazenda São José, and have been 


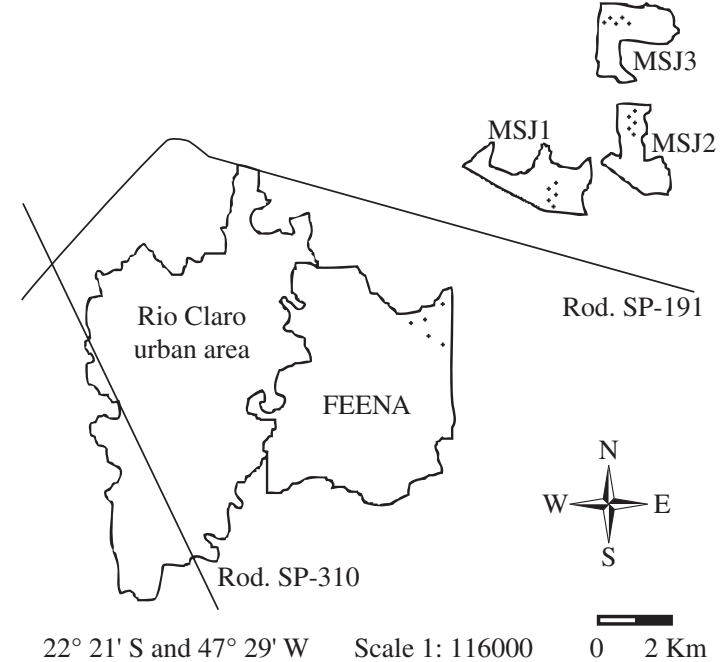

Figure 1. The study areas, MSJ (Mata São José) forest fragments and FEENA (Floresta Estadual Edmundo Navarro de Andrade), with the approximate location of collecting points (dots).

isolated from each other by crops since 1939. The habitat in these fragments is characterized as seasonal semideciduous forest, or inland Atlantic Forest (Oliveira and Fontes, 2000), with a $30 \mathrm{~m}$ tall canopy (Pagano et al., 1995). From 20 to $50 \%$ of the trees lose their leaves in the dry season (Oliveira and Fontes, 2000).

The FEENA $\left(22^{\circ} 21^{\prime} \mathrm{S}\right.$ and $\left.47^{\circ} 30^{\prime} \mathrm{W}\right)$, in its western portion, is continuous to the Rio Claro urban spot, and comprehends an area of about 2250 ha. It was created in 1909 as an Eucalyptus research and production center for a state railroad company. Thus, 38 million individuals, belonging to over 150 Eucalyptus species brought from Australia, were planted there. The age of the cultivated lots ranges from 5 to 90 years, with the older lots showing a well-developed understory, since they have not been disturbed for a longer time (Moura, 1998). The smallest distance between FEENA and the three fragments (MSJ1 is the closest to FEENA) is of approximately $2 \mathrm{~km}$.

\subsection{Ant collection}

We collected ants in the four mentioned areas (FEENA and the three fragments) once in the rainy season and again in the dry season, using pitfall traps (Majer, 1978). In the native forest fragments, traps were installed in five points along the trail that crosses each fragment. The first point distanced ca. $200 \mathrm{~m}$ from the fragment entry, and the additional four points distanced ca. $150 \mathrm{~m}$ from each other, toward the interior of the fragment (Figure 1). In FEENA, each one of the five points were located in a different lot, randomly chosen, in the northeast region of FEENA, since it is the area that is physically closest to MSJ (Figure 1). Three of the lots (named 91, 120 and 120B) presented Eucalyptus cultivation with a well-developed understory, holding some of the region's native elements (Moura, 1998; D. M. Lapola, pers. obs.). The fourth lot (number 92) was a Pinus cultivation, almost entirely without understory. The last point was located in a lot (number 93) of 3.4 ha destined for native species cultivation and, hence, very related to the native MSJ fragments.

On each of the five points 20 pitfall traps were installed, forming a $15 \times 20 \mathrm{~m}$ quadrat, with traps distancing $5 \mathrm{~m}$ from each other (in a parallel sense), totalizing 100 traps in each one of the four areas (FEENA, MSJ1, MSJ2 and MSJ3). After avoiding digging-in effects (Greenslade, 1973), traps operated for 72 hours in the summer collection and 120 hours in the winter one. Subsequently to that, ants were removed, mounted and identified until species or morpho-species level. All voucher specimens are deposited in the collection of the Department of Ecology in the Universidade Estadual Paulista, Rio Claro. Morpho-species already present in that collection were named by number, while those not previously contained in the collection were referred by a letter.

\subsection{Data analysis}

In order to determine the similarity between the ant communities of FEENA and MSJ, we compared the ant species of the four areas according to their identities. To do that we used the Jaccard similarity index $\left(\mathrm{C}_{\mathrm{j}}\right)$ (Jaccard, 1901). The simplicity of this index is desirable in our case, since it considers only the presence/absence of each species in each area, and studies concerning ants (and other social insects) that take into account the abundance of these insects, are of difficult interpretation (Wilson, 1971). A C $\mathrm{j}_{\mathrm{j}}$ value of 1 represents total similarity between the areas, and a value equal to 0 means that both areas are different and do not share any species (Magurran, 1988). The index was applied for two areas at a time, adding up six comparisons (MSJ1 x MSJ2, MSJ1 x MSJ3, MSJ2 x MSJ3, MSJ1 x FEENA, MSJ2 x FEENA and MSJ3 $x$ FEENA). With the weighted means of the results of such comparisons we confectioned a dendrograph that allowed us to visualize the level similarity between the four areas.

Furthermore, to perform a diversity analysis that could take into account the abundance of collected species, we calculated the Shannon-Weiner entropy index (H')(Magurran, 1988; Jost, 2006) for the four studied areas. The conversion of the index values to absolute number of species (Jost, 2006) allowed us to compare the real magnitude of the differences in Shannon-Weiner index for the four mentioned areas. Considering the above cited difficulties of dealing with abundance of social insects, the abundance of each species used in the calculation of this index was the percentage of pitfalls in which the species occurred. We also present a measure of evenness $\left[\mathrm{E}=\mathrm{H}^{\prime} / \mathrm{ln}\right.$ (species richness)] which indicates how similar the abundance organization of different communities are. When there are similar proportions of all species then evenness is one, and when the abundances are very dissimilar then the value decreases to zero. 


\section{Results}

We collected a total of 1798 ants organized in 96 species and 31 genera belonging to 8 subfamilies in all the four areas (FEENA and the three MSJ fragments). The Pheidole genus, as praxis in Neotropics, was the most diverse, with 24 different species, representing $25 \%$ of all collected species. Diversity, in number of species, was practically the same in the four areas: 44 species in FEENA; 49 in MSJ1; 42 in MSJ2; and 48 in MSJ3 (Table 1). Only 12 species were found in all the four areas (see Table 2).

Through calculation of the Jaccard index $\left(\mathrm{C}_{\mathrm{j}}\right)$ we obtained that the ant communities of FEENA share $29 \%$ of its species with the MSJ forest fragments (FEENA x MSJ1, MSJ2 and MSJ3: $\left.\overline{\mathrm{C}}_{\mathrm{J}}=0,29 \pm 0,02\right)$. On the other hand, this value increased to $40 \%$ of species shared between the MSJ fragments (MSJ1, 2 and 3 x MSJ1, MSJ2 and MSJ3:

Table 1. Observed species richness, mean Jaccard values, Shannon-Weiner entropy index, the same index converted to absolute number of species (Jost, 2006) and evenness for the ant communities of Northeastern FEENA and MSJ forest fragments.

\begin{tabular}{lrrrr}
\hline & FEENA & MSJ1 & MSJ2 & MSJ3 \\
\hline Species richness & 44 & 49 & 42 & 48 \\
Jaccard (C) & 0.29 & 0.36 & 0.39 & 0.33 \\
Shannon-Weiner (H') & 3.39 & 3.50 & 3.34 & 3.39 \\
H' number of spp. & 29 & 33 & 28 & 29 \\
Evenness (E) & 0.89 & 0.90 & 0.89 & 0.87 \\
\hline
\end{tabular}

$\overline{\mathrm{C}}_{\mathrm{J}}=0.40 \pm 0.06$ ) (Table 1). In the dendrograph (Figure 2) we can visualize that the three forest fragments belong to a separate group, or are more similar among themselves than to FEENA. Furthermore, FEENA appears in the dendrograph as an isolated segment, evidencing its difference in relation to the other three areas.

Contrastingly, the Shannon-Weiner index showed rather similar diversity values for the studied areas (Table 1), which is clearly perceived when converting these values to absolute number of species (Jost, 2006): FEENA $=29 ;$ MSJ1 = 33; MSJ2 = 28; MSJ3 = 29. Such similarity was also found for the measure of evenness (Table 1), indicating the same abundance organization for the four communities.

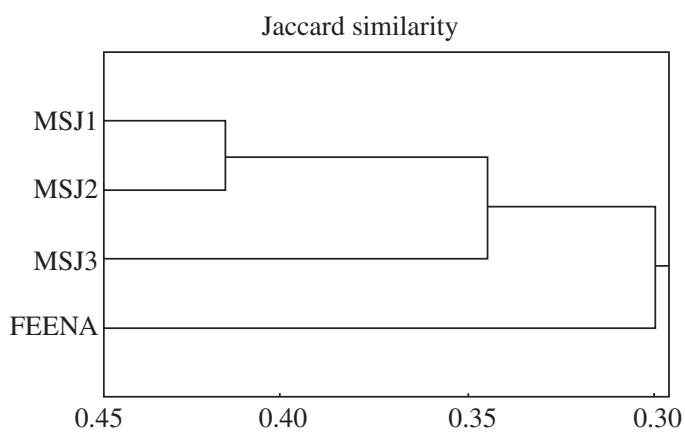

Figure 2. Jaccard similarity dendrograph for the ant communities of three inland Atlantic Forest fragments (Mata São José - MSJ1, MSJ2 and MSJ3) and an Eucalyptus reforestation (Floresta Estadual Edmundo Navarro de Andrade - FEENA in its Northeastern part).

Table 2. Ant species collected with pitfall traps in Northeastern FEENA and in the MSJ1, MSJ2 and MSJ3 forest fragments, separated by subfamily. The percentage value means presence of the species in the referred area and its relative abundance (number of pitfalls in which the species occurred).

\begin{tabular}{|c|c|c|c|c|}
\hline $\begin{array}{c}\text { Subfamily } \\
\text { Species }\end{array}$ & $\begin{array}{c}\text { FEENA } \\
(\%)\end{array}$ & $\begin{array}{c}\text { MSJ1 } \\
(\%)\end{array}$ & $\begin{array}{c}\text { MSJ2 } \\
(\%)\end{array}$ & $\begin{array}{c}\text { MSJ3 } \\
(\%)\end{array}$ \\
\hline \multicolumn{5}{|l|}{ Ectatomminae } \\
\hline Ectatomma edentatum Roger & 3 & 9 & 17 & 9 \\
\hline Gnamptogenys striatula Mayr & 7 & 4 & & 25 \\
\hline Gnamptogenys acuminata Emery & - & - & - & 1 \\
\hline Typhlomyrmex major Santschi & 1 & - & - & - \\
\hline \multicolumn{5}{|l|}{ Heteroponerinae } \\
\hline Heteroponera sp. & - & - & - & 1 \\
\hline \multicolumn{5}{|l|}{ Ponerinae } \\
\hline Hypoponera sp.A & - & 2 & 1 & - \\
\hline Hypoponera sp.B & 2 & 3 & 1 & 1 \\
\hline Hypoponera sp.C & - & 3 & - & - \\
\hline Hypoponera sp.D & - & 2 & - & - \\
\hline Hypoponera sp.E & 1 & - & - & - \\
\hline Hypoponera sp.F & 1 & - & 1 & - \\
\hline Hypoponera sp.G & 2 & 1 & - & - \\
\hline Hypoponera sp.H & - & - & 1 & - \\
\hline
\end{tabular}


Table 2. Continued...

\begin{tabular}{|c|c|c|c|c|}
\hline $\begin{array}{r}\text { Subfamily } \\
\text { Species }\end{array}$ & $\begin{array}{c}\text { FEENA } \\
(\%)\end{array}$ & $\begin{array}{c}\text { MSJ1 } \\
(\%)\end{array}$ & $\begin{array}{c}\text { MSJ2 } \\
(\%)\end{array}$ & $\begin{array}{c}\text { MSJ3 } \\
(\%)\end{array}$ \\
\hline Hypoponera sp.I & - & - & 1 & - \\
\hline Odontomachus chelifer Latreille & 2 & 5 & 2 & 3 \\
\hline Odontomachus meinerti Forel & 1 & 3 & 4 & 1 \\
\hline Pachycondyla harpax Fabricius & 1 & 1 & 2 & 3 \\
\hline Pachycondyla obscuricornis Emery & 1 & - & - & - \\
\hline Pachycondyla striata F. Smith & 11 & 5 & 4 & 9 \\
\hline Pachycondyla sp. & - & 1 & - & - \\
\hline \multicolumn{5}{|l|}{ Ecitoninae } \\
\hline Eciton quadriglume Haliday & - & 1 & - & - \\
\hline Labidus praedator Smith & 3 & 9 & 2 & - \\
\hline Labidus coecus Latreille & - & 3 & 5 & 14 \\
\hline \multicolumn{5}{|l|}{ Dolichoderinae } \\
\hline Linepithema humile Mayr & - & - & - & 1 \\
\hline Tapinoma melanocephalum Fabricius & - & - & - & 1 \\
\hline \multicolumn{5}{|l|}{ Formicinae } \\
\hline Brachymyrmex sp.A & 7 & 2 & - & 1 \\
\hline Brachymyrmex sp.B & 1 & - & - & 3 \\
\hline Brachymyrmex sp.C & - & - & 1 & - \\
\hline Brachymyrmex sp.D & 1 & - & - & 1 \\
\hline Camponotus rufipes Fabricius & - & 1 & 2 & - \\
\hline Camponotus sp.A & 2 & 3 & 1 & - \\
\hline Camponotus sp.B & - & - & 1 & - \\
\hline Camponotus sp.C & - & - & 1 & - \\
\hline \multicolumn{5}{|l|}{ Pseudomyrmecinae } \\
\hline Pseudomyrmex (gr. gracilis) sp. & 1 & - & - & - \\
\hline \multicolumn{5}{|l|}{ Myrmicinae } \\
\hline Acromyrmex coronatus Fabricius & - & - & 1 & 7 \\
\hline Acromyrmex subterraneus Forel & - & 2 & - & - \\
\hline Apterostigma sp. & - & 4 & 1 & 7 \\
\hline Atta sexdens Forel & 6 & - & 4 & 6 \\
\hline Basiceros disciger Mayr & - & 1 & - & - \\
\hline Carebara sp.A & - & 1 & - & - \\
\hline Carebara sp.B & 4 & - & - & - \\
\hline Crematogaster sp.A & 1 & - & - & - \\
\hline Crematogaster sp.B & - & - & - & 1 \\
\hline Crematogaster sp.C & - & - & - & 1 \\
\hline Cyphomyrmex bicornis Forel & 1 & - & 1 & - \\
\hline Cyphomyrmex laevigatus Weber & - & - & - & 1 \\
\hline Cyphomyrmex major Forel & - & - & - & 1 \\
\hline Cyphomyrmex (gr.strigatus) sp.A & - & 1 & - & - \\
\hline Cyphomyrmex (gr. strigatus) sp.B & - & - & - & 1 \\
\hline Cyphomyrmex (gr. strigatus) sp.C & - & - & - & 1 \\
\hline Hylomyrma balzani Emery & - & 1 & - & - \\
\hline Hylomyrma reitteri Mayr & - & 1 & - & - \\
\hline
\end{tabular}


Table 2. Continued...

\begin{tabular}{|c|c|c|c|c|}
\hline $\begin{array}{r}\text { Subfamily } \\
\text { Species }\end{array}$ & $\begin{array}{c}\text { FEENA } \\
(\%)\end{array}$ & $\begin{array}{c}\text { MSJ1 } \\
(\%)\end{array}$ & $\begin{array}{c}\text { MSJ2 } \\
(\%)\end{array}$ & $\begin{array}{c}\text { MSJ3 } \\
(\%)\end{array}$ \\
\hline Monomorium floricola Jerdon & - & 2 & - & - \\
\hline Nesomyrmex sp. & - & - & - & 1 \\
\hline Oxyepoecus vezenyii Forel & 1 & - & - & - \\
\hline Pheidole sp.6 & 1 & 7 & 5 & 3 \\
\hline Pheidole sp.22 & 14 & 2 & 4 & - \\
\hline Pheidole sp.26 & 1 & - & - & 1 \\
\hline Pheidole sp.48 & 3 & 7 & 4 & 5 \\
\hline Pheidole sp.A & - & 1 & 2 & 2 \\
\hline Pheidole sp.B & 3 & 2 & 11 & 2 \\
\hline Pheidole sp.C & - & 1 & 3 & 6 \\
\hline Pheidole sp.D & 1 & 1 & - & - \\
\hline Pheidole sp.E & 6 & - & 5 & 2 \\
\hline Pheidole sp.F & - & - & 10 & \\
\hline Pheidole sp.H & - & 2 & 5 & 2 \\
\hline Pheidole sp.I & - & 2 & 6 & 7 \\
\hline Pheidole sp.J & - & 15 & 9 & 10 \\
\hline Pheidole sp.K & - & 2 & 2 & 1 \\
\hline Pheidole sp.L & 9 & - & - & - \\
\hline Pheidole sp.M & 1 & - & - & - \\
\hline Pheidole sp.N & 1 & - & - & - \\
\hline Pheidole sp.O & 1 & - & - & - \\
\hline Pheidole sp.P & - & 1 & - & 4 \\
\hline Pheidole sp.Q & - & 1 & - & - \\
\hline Pheidole sp.R & 1 & - & - & - \\
\hline Pheidole sp.S & - & - & - & 2 \\
\hline Pheidole sp.T & - & - & 1 & 1 \\
\hline Pheidole sp.U & 1 & - & - & - \\
\hline Pyramica denticulata Mayr & - & 1 & 1 & - \\
\hline Solenopsis (Diplorhoptrum) sp.2 & 2 & 6 & 1 & - \\
\hline Solenopsis (Diplorhoptrum) sp.3 & 3 & 8 & 5 & 10 \\
\hline Solenopsis (Diplorhoptrum) sp.A & 6 & 4 & 16 & 7 \\
\hline Solenopsis (Diplorhoptrum) sp.B & 4 & 15 & 9 & 6 \\
\hline Solenopsis (Diplorhoptrum) sp.C & - & - & 3 & 2 \\
\hline Solenopsis (Diplorhoptrum) sp.D & - & - & - & 2 \\
\hline Solenopsis sp.E & 1 & - & - & - \\
\hline Solenopsis sp.F & - & 1 & - & - \\
\hline Solenopsis sp.G & 3 & - & - & - \\
\hline Solenopsis sp.H & - & - & - & 1 \\
\hline Strumigenys elongata Roger & - & 1 & - & - \\
\hline Strumigenys louisianae Roger & 1 & - & - & 1 \\
\hline Trachymyrmex dichrous Kempf & - & - & - & 1 \\
\hline Trachymyrmex sp. & - & 2 & - & - \\
\hline Wasmannia auropunctata Roger & 7 & 7 & 1 & - \\
\hline Wasmannia rochai & - & 1 & 6 & 4 \\
\hline Pitfalls which captured ants & 65 & 75 & 82 & 83 \\
\hline
\end{tabular}


The efficiency of pitfalls was of approximately $76 \%$, which means that only about 24 , from the total of 100 pitfall traps in each area, did not collect any ant individual (see last line of Table 2).

\section{Discussion}

We found that the ant communities of the three forest fragments (MSJ) are more similar among themselves than to the FEENA community when regarding their identity (Figure 2), but these communities are quite similar in number of species and abundance organization (Table 1). Our results are contrasting with those of Marinho et al. (2002): while in that study they found a similarity of approximately $40 \%$ between an Eucalyptus area and a natural Cerrado, in our case this value decreases to $29 \%$. In spite of showing practically the same diversity in number of species (as in Marinho et al., 2002 and other studies), we could find some particular distinctions in the identity of ant fauna collected in FEENA and in MSJ, in addition to what can be seen in the dendrograph. In MSJ, species of the fungus-growing tribe Attini make up $15 \%$ of the ant community, while in FEENA it is present only in $4 \%$, being replaced by generalized Myrmicinae like Pheidole, which compounds $30 \%$ of the community in FEENA and $22 \%$ in MSJ. Ants like Apterostigma, Basiceros, Cyphomyrmex, Trachymyrmex and Eciton, present in our collections in MSJ and not in those of FEENA, are typical of natural forested environments and rely upon specific conditions of shading, moisture and temperature to survive. These species also require microhabitats that only a native forest litter can provide to maintain their nests and forage in it (Fowler et al., 1991; Gotwald, 1995). Otherwise, in FEENA it is noteworthy the absence in our samples of these forest species (see Table 2), possibly demonstrating the level of stress and perturbation of FEENA's environment. But it is also noticeable the presence of an individual of the Old World exotic species Monomorium floricola in our MSJ1 sample.

We think that two specific factors of the studied areas can explain that difference in the identity of the communities: 1) level of soil compactness, caused by human intervention in these areas, and 2) litter structure. As discussed below, these two factors are crucial to the establishment and maintenance of terrestrial ant communities in native tropical forests.

1) The level of soil compactness affects incisively the ant communities to be installed in it, mainly those ants that nest underground, since they will spend more energy in excavation in compacted soils (Hölldobler and Wilson, 1990; Lapola et al., 2003). In view of the fact that a lot of ant species exhibit migratory habits (varying from days to some years), an excessive loss of energy in the excavation of nests that will be shortly used is not a fair trade for ants, specially for those species evolutionarily adapted to nest in less compacted soils (Hölldobler and Wilson, 1990; Lapola et al., 2003). The soils where we operated the collections in FEENA are more compacted than the soils of the other three areas of native forest, at least in the upper $20 \mathrm{~cm}$ (which is the layer most populated by invertebrates), as we noticed when digging to install pitfalls. This assumption becomes evident if we mind that the FEENA area has been suffering approximately a 150-200 years history of human intervention. Before being an Eucalyptus experimental station the area held, in its almost totality, coffee plantations (Dean, 1976). This represents, at least, two centuries of human activities, which certainly caused soil compaction in the area where we find FEENA today. Furthermore, some practices used nowadays, such as the use of tractors, surely still contribute to this process. On the other hand, the forest fragments have never had even its natural vegetation cover suppressed (possibly it had only a selective cut of some valued trees in the mid- $20^{\text {th }}$ century). So we can state that in MSJ the soil has kept its natural level of compaction, thus providing an ideal environment for the nesting of region's native ant species. Otherwise, the compacted soils of FEENA can represent an obstacle for the establishment of native (typical of forests) ant colonies, what reflected in differences in the identity of ant communities of MSJ and FEENA; and

2) A deep, complex leaf litter as we see in a tropical forest like MSJ, beyond providing refuges where ants nest, also bear a great amount of other invertebrates that serve as prey to ants or operate other diverse ecological functions (Wilson, 1959; Majer and Recher, 1999). The activities of the organisms that occur in litter enclose processes of fundamental importance in a forest ecosystem (Wilson, 1987; Majer and Recher, 1999). It has been clear that the litter of Eucalyptus reforestations (like FEENA) is different and probably less complex than one of a native forest (like MSJ) (Vallejo et al., 1987; Oliveira et al., 1995; Lima, 1996, Majer and Recher, 1999; but see Marinho et al., 2002). Farther than Eucalyptus cultivation being a potential cause of erosion, some studies suggest that Eucalyptus has an abiotic effect on the micro fauna of soil (notice that the lowest pitfall efficiency was in FEENA, Table 2). Others argue that it is not due to the litter per se, but to a microclimatic alteration that the Eucalyptus plantation exerts in the soil once implemented (Vallejo et al., 1987; Oliveira et al., 1995; Lima, 1996; Majer and Recher, 1999). Therefore, if FEENA and MSJ have different litters, certainly it causes a difference in the ant fauna (and perhaps other invertebrates) too, for it is in litter where these animals forage, nest etc (Hölldobler and Wilson, 1990). 
Once the difference in Jaccard similarity between FEENA and MSJ was not very great, one can argue that it is possibly caused purely by geographic effects, and not by the difference in vegetation cover of the areas. That is, the forest fragments are more similar among themselves only for being closer to each other, and even if the FEENA area were a native forest, these areas would present the same similarity of $29 \%$ as they presented here. Beyond what was explained above, other evidences can discard this hypothesis too: the lowest similarity values were among closest areas (FEENA x MSJ1, and FEENA x MSJ2, see Figures 1 and 2). The proximity of MSJ3 to FEENA in the dendrograph is probably due to a close level of stress/perturbation that these two areas present, and not due to a physical proximity, since they are the most distanced areas of our study. In addition of being the smallest fragment, MSJ3 is found at the top of a hill, and perhaps is stressed by wind flow and water deficit, what reflected in its proximity to FEENA in the dendrograph (resulting in the occurrence in our collections of two tramp species in MSJ3, Linepithema humile and Tapinoma melanocephalum).

The fact of FEENA, as well as MSJ fragments, show the same diversity in number of species and evenness, as revealed by the Shannon-Weiner index analysis (Table 1), was an already expected result (like in Marinho et al., 2002). As the majority of invertebrates, ants are small organisms and disperse rapidly, thus being fast to occupy empty niches, principally in the tropics. But in the case of FEENA, once the vegetation and the habitat as a whole are more anthropogenic than MSJ, it is certain that the community to be installed there will be forced to hold ants adapted to the Eucalyptus environment. This might lead to a community different from a community formed in a native forest, as evidenced in our results and in other studies (e.g. Vallejo et al., 1987; Oliveira et al., 1995). But besides that, we encourage more intensive studies, dealing with other taxa, to elucidate if this difference is applicable to other organisms and to certify if it is due only to geographical effects or if it is indeed driven by a difference in the vegetation cover of FEENA and MSJ. It is important to cite that our results also contrast with those for the highmobility birds group. While less than $30 \%$ of ant species from the three MSJ fragments also occur in FEENA, birds share about $70 \%$ of its species between FEENA and MSJ1 (considering strictly forest and border bird species of these two areas) (Willis, 2003; Willis Oniki, 2002).

\section{Conclusions}

We gave evidences for the difference between FEENA and MSJ in another biota segment, in addition to the previously known difference in the vegetation segment. What then can we tell about the proposal of a habitat corridor connecting FEENA to MSJ? In these cases, since the finances for these tasks are always limited, the actions must be taken in order of priority. It is obvious that, for conservation purposes, priority must be given to natural communities, or closer to natural communities, which have been constituted through natural processes. All MSJ fragments, as well as FEENA, demonstrated being important areas for conservation of native ant species of the region. In view of our results, we think that at this moment it is important to focus efforts on the conservation of the three MSJ fragments, once they represent the biggest areas of native vegetation in the region of Rio Claro. Among these efforts, the implementation of corridors connecting MSJ1, MSJ2 and MSJ3 would be interesting, and independently if they will work or not, it would not cause harm, once the communities there were constituted with relative little human intervention, and are quite similar to each other.

Similarly, the implementation of a habitat corridor connecting FEENA to MSJ would also be a good effort toward the conservation of the regional ant fauna since we did not find important exotic/tramp ant species in our FEENA samples that could threat the MSJ ant fauna. So if this corridor really works, it would be desirable since with time it would probably make the ant communities of FEENA get similar to MSJ, closer to a native environment. It is important though to be aware of the differences in the identity and history of formation of the communities of MSJ and FEENA presented here. Furthermore, the subtle differences in the micro-habitats of FEENA and MSJ would cause some ant species (for example those present in MSJ and not in FEENA) not to adapt in a different environment, which, from this point of view, would turn the corridor useless. Thus we consider that the successional process of FEENA's flora and fauna must occur without this kind of "help" from MSJ, but with the gradual cut of Eucalyptus trees and cultivation of native species, which would certainly be cheaper and more effective than implementing a habitat corridor (opposing Willis, 2003).

The proposal of connecting FEENA to MSJ through a corridor, which was conceived by researchers and up to a certain point accepted by FEENA administration, is a clear example of a public policy (almost) effectuated without support of scientific knowledge. With the advent of Kyoto Protocol, and consolidation of carbon trade market, we can expect an increase in areas of reforestation in the country (Brasil, 1997). This in turn can also increase the confusion in distinguishing a native forest remnant from a non-native reforestation, which is particularly worrying if this confusion comes from the decision-makers. Thus we emphasize here the importance of previous scientific research, as the present study, supporting public policies on biodiversity conservation in Brazil.

Acknowledgments - We wish to thank H. L. Vasconcelos, C. R. F. Brandão, C. M. Reis (FEENA administration), M. I. Pagani, L. C. S. Figueiredo, O. Nardy and an anonymous reviewer for discussions and valuable comments on this manuscript. We are also grateful to all friends who helped in fieldwork, especially F. S. Andriolli and S. Nazareth. S. Veloso helped with ant mounting and F. J. Zara with identification of Ecitoninae and Pachycondyla specimens. Thanks also to the Instituto Florestal, which gave us permission to conduct our research in FEENA, and to the Fazenda São José owner, for allowing us to do our work in his 
property. The Instituto de Biociências of Universidade Estadual Paulista in Rio Claro for logistical help and FAPESP for the financial support (D.M.L., Proc. nº 02/10392-9).

\section{References}

ALONSO, LE. and AGOSTI, D., 2000. Biodiversity studies, monitoring, and ants: an overview, In AGOSTI D., MAJER, J., ALONSO, LE., SCHULTZ, T. (Eds.), Ants: standard methods for measuring and monitoring biodiversity. Smithsonian Institution Press, Washington (DC), p. 1-8.

BEIER, P. and NOSS, R., 1998. Do habitat corridors provide connectivity? Conserv. Biol., vol. 12, no. 6, p. 1241-1252.

BIERREGAARD-JR, RO., LOVEJOY, TE., KAPOS, V., SANTOS, AA. and HUTCHINGS, RW., 1992. The biological dynamics of tropical rainforest fragments. BioScience, vol. 42, no. 11, p. $859-866$.

BRASIL, 1997. Protocolo de Quioto. Ministério da Ciência e Tecnologia, Secretaria Especial de Edições Técnicas, Brasília (DF), $29 \mathrm{p}$.

BROWN JR, KS. and BROWN, GG., 1992. Habitat alteration and species loss in Brazilian forests. In WHITMORE, TC. and SAYER, JA. (Eds.), Tropical deforestation and especies extinction. Chapman and Hall, London, p. 119-142.

CONSERVATION INTERNATIONAL BRASIL, 2006. Corredores de Biodiversidade. Available at: http://www. conservation.org.br/como/index.php?id=10, [accessed in January 24, 2006].

DEAN, WB., 1976. Rio Claro: a Brazilian plantation system, 1820-1920. Stanford University Press, Stanford (CA), 234 p.

-, 1995. With broadax and firebrand: the destruction of the Brazilian Atlantic Forest. University of California Press, Berkeley (CA), 504 p.

FOWLER, HG., FORTI, LC., BRANDÃO, CRF., DELABIE, JHC. and VASCONCELOS, HL., 1991. Ecologia nutricional de formigas. In PANIZZI, AR. and PARRA, JRP. (Eds.), Ecologia nutricional de insetos e suas implicações no manejo de pragas. Manole, São Paulo (SP), p. 131-223.

FURTADO, F., 2005. Conservação em dose dupla. Ciência Hoje, vol. 35, no. 220, p. 53-55.

GASCON, C., LAURANCE, WF. and LOVEJOY, TE., 2002. Fragmentação florestal e biodiversidade na Amazônia central. In DIAS, BFS. and GARAY, I. (Eds.), Conservação da biodiversidade em ecossistemas tropicais: avanços conceituais e revisão de novas metodologias de avaliação e monitoramento. Vozes, Petrópolis (RJ), p. 112-127.

GOTWALD JR, WH., 1995. Army ants. Cornell University Press, New York (NY), 302 p.

GREENSLADE, P., 1973. Sampling ants with pitfall traps: digging-in effects. Insectes Soc., vol. 20, no. 4, p. 343-353.

HÖLLDOBLER, B. and WILSON, EO., 1990. The ants. Belknap Press, Cambridge (MA), 732 p.

IPÊ, 2006. Projeto corredores agroflorestais (Programa Pontal do Paranapanema). Available at: http://www.ipe. org.br/html/programas_pontal_corredores.htm, [accessed in January 24, 2006].
JACCARD, P., 1901. Distribution de la flore alpine dans le Bassin des Drasnes et dans quelques régions voisines. Bull. Soc. Vaud. Sc. Nat., no. 44, p. 223-270.

JOST, L., 2006. Entropy and diversity. Oikos, vol. 113, no. 2, p. 363-375.

KRONKA, FJN., NALON, MA. and MATSUKUMA, CK., 2005. Inventário florestal da vegetação natural do Estado de São Paulo. Secretaria do Meio Ambiente, Instituto Florestal, São Paulo (SP), 200 p.

LAPOLA, DM., ANTONIALLI-JR, WF. and GIANNOTTI, E., 2003. Arquitetura de ninhos da formiga neotropical Ectatomma brunneum F. SMITH, 1858 (Formicidae, Ponerinae) em ambientes alterados. Rev. Brasil. Zoociências, vol. 5, no. 2, p. 177-188.

LEVEY, DJ., BOLKER, BM., TEWKSBURY, JJ., SARGENT, S. and HADDAD NM., 2005. Effects of landscape corridors on seed dispersal by birds. Science, vol. 309, no. 5731, p. 146-148.

LIMA, WP., 1996. Impacto ambiental do eucalipto. EDUSP, São Paulo (SP), 301 p.

MAGURRAN, AE., 1988. Ecological diversity and its measurement. Princeton University Press, Princeton (NH), 192 p.

MAJER, JD., 1978. An improved pitfall trap for sampling ants and other epigaeic invertebrates. J. Aust. Entomol. Soc., vol. 17, no. 3, p. 261-262.

MAJER, JD. and RECHER, H., 1999. Are eucaliptus Brazil's friend or foe? An entomological viewpoint. An. Soc. Entomol. Brasil, vol. 28, no. 2, p. 185-200.

MARINHO, CGS., ZANETTI, R., DELABIE, JHC., SCHLINDWEIN, MN. and RAMOS, LS., 2002. Diversidade de formigas (Hymenoptera: Formicidae) da serapilheira em eucaliptais (Myrtaceae) e área de Cerrado de Minas Gerais. Neotrop. Entomol., vol. 31, no. 2, p. 187-195.

MCGLYNN, TP., 1999. The worldwide transfer of ants: geographical distributions and ecological invasions. J. Biogeogr., vol. 26 , no. 3 , p. $535-548$.

MOURA, LC., 1998. Um estudo de estrutura de comunidade em fitocenoses originárias da exploração e abandono de plantios de eucalipto, localizadas no Horto Florestal Navarro de Andrade, Rio Claro (SP). (Tese de Doutorado) - IB/UNICAMP, Campinas, SP, $340 \mathrm{p}$.

NOSS, RF., 1987. Corridors in real landscapes: a reply to Simberloff and Cox. Conserv. Biol., vol. 1, no. 2, p. 159-164.

OLIVEIRA, AT. and FONTES, MAL., 2000. Patterns of floristic differentiation among Atlantic forests in southeastern Brazil and the influence of climate. Biotropica, vol. 32, no 4b, p. 793-810.

OLIVEIRA, MA., DELLA LUCIA, TMC., ARAÚJO, AP. and DA CRUZ, AP., 1995. A fauna de formigas em povoamentos de eucalipto na mata nativa no estado do Amapá. Acta Amazonica, vol. 25, no 1-2, p. 117-126.

PAGANO, SN., LEITÃO, HF. AND CASSAVAN, O., 1995. Variação temporal da composição florística e estrutura fitossociológica de uma floresta mesófila semidecídua - Rio Claro - Estado de São Paulo. Rev. Brasil. Biol., vol. 55, no. 2, p. 241-258. 
SCHULTZ, TR. and MCGLYNN, TP., 2000. The interactions of ants with other organisms. In: AGOSTI D., Majer, J., Alonso, LE., Schultz, T. (Eds.), Ants: standard methods for measuring and monitoring biodiversity. Smithsonian Institution Press, Washington (DC), p. 35-44.

SIMBERLOFF, D., FARR, JA., COX, J. and MEHLMAN, DW., 1992. Movement corridors: conservation bargains or poor investments? Conserv. Biol., vol. 6, no. 4, p. 493-504.

VALLEJO, LR., FONSECA, CL. and GONÇALVES, DRP.,1987. Estudo comparativo da mesofauna do solo em áreas de Eucaliptus citriodora e mata secundária heterogênea. Rev. Brasil. Biol., vol. 47, no. 3, p. 363-370.

WILLIAMSON, M. and FITTER, A., 1996. The varying success of invaders. Ecology, vol. 77, no. 6, p. 1661-1666.

WILLIS, EO., 2003. Birds of a eucalyptus woodlot in interior São Paulo. Brazil. J. Biol., vol. 63, no. 1, p. 141-158.
-, EO. and ONIKI, Y., 2002. Birds of a central São Paulo woodlot: 1. censuses 1982-2000. Brazil. J. Biol., vol. 62, no. 2, p. 197-210.

WILSON, EO., 1959. Some ecological characteristics of ants in New Guinea rain forests. Ecology, vol. 40, no. 3, p. 437-447.

-, 1971. The insect societies. Belknap Press, Cambridge (MA), $548 \mathrm{p}$.

-, 1987. The little things that run the world (the importance and conservation of invertebrates). Conserv. Biol., vol. 1, no. 4, p. 344-346.

WILSON, EO. and WILLIS, EO., 1975. Applied biogeography. In: Cody, ML. and Diamond, JM. (Eds.), Ecology and evolution of communities. Harvard University Press, Cambridge (MA), p. 523-534.

ZORZETTO, R., FIORAVANTI, C. and FERRONI, M., 2003. A floresta renasce. Pesquisa FAPESP, no. 91, p. 48-53. 